\title{
GAME OF THRONES: THE BATTLE OF THE MPHEPHUS
}

\author{
by Gudani Tshikota*
}

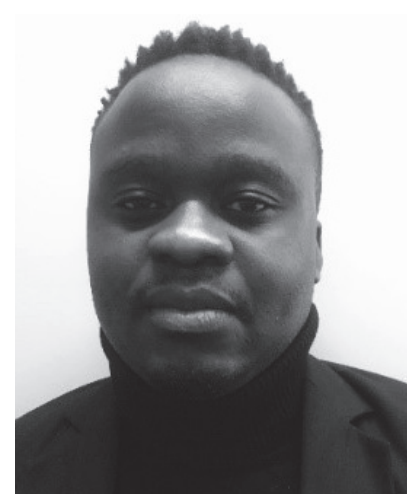

Munwali ndi Gudani Tshikota. Ndi muvenda mubikwa na ive, ive la vhibva nne nda sala. Ndi mukololo, sa mukololo, ndi nwala nga u ditukufhadza nahone ndi so ngo divhudza u nyadza nndu khulu ya musanda haMphephu Ramabulana. ${ }^{1}$

'Singo langa rambau. Sunguzwi i a dzudzumela i nyaga u tiba Makhado Tshilwavhusiku tshaha Ramabulana.'2

\section{Introduction/Mathomo}

South Africa, like the whole of Africa and many parts of the world, was not immune to Western civilisation, and this 'civilisation' was accompanied by the imposition of Western ideas, laws, cultures and

* $\quad$ Final year LLB student, University of Pretoria. ORCID: 0000-0001-5967-3101. I dedicate this paper to Prof Charles Maimela. His contribution and involvement in my understanding and knowledge of customary law in South Africa has been incredible. I would also like to acknowledge and give my utmost gratitude to my mentor Dr Joel Modiri for his contribution towards my critical thinking and writing skills and making sure I read and write more often. Prof Nicholaus Nelson-Goedert has also been very influential in ensuring that I acquire analytical reasoning and writing skills. Suzan Tshilivhali Tshikota and Karabo Tshikota remain the root of everything.

1 Here I introduce myself and reveal that I am a Venda young man born between the royal families of Tshikota and Vele. I note with great humility that this writing is not intended to dishonour or disrespect the great royal house of the Vhavenda people.

2 Here I praise the clan names of the Mphephu Ramabulana family, showing salutation and humility. This was written by Mbulaheni Mphephu and it is to be found here http://www.wakahina.co.za/listings//surname/mphephu. 
traditions, and many other attributes of conquest. ${ }^{3}$ African law was infiltrated and distorted beyond recognition, resulting in the origination of 'official' customary law, which remains stagnant and incapable of accounting for the needs, values and circumstances of an ever-changing society. ${ }^{4}$ This study looks at the battle for the Vhavenda kingship/queenship between Masindi Mphephu (hereafter 'Masindi') and Toni Peter Mphephu (hereafter 'Toni') and contends that the Supreme Court of Appeal's decision was correct in light of the values enshrined in our constitutional democracy. ${ }^{5}$ This is done by looking at the decision pertaining to the principle of male primogeniture in Bhe and Others $v$ Khayelitsha Magistrate and Others (hereafter 'the Bhe case') and succession in Shilubana and Others $v$ Nwamitwa (hereafter 'the Shilubana case'). ${ }^{6}$ Throughout this study, the adoption of 'living' customary law by judicial systems and the legislature is proposed as a catalyst towards the transformation of customary law. ${ }^{7}$ Finally, this study contends that the pronouncement of Masindi as queen would be a step towards the transformation of customary law. 8

\section{The battle for the throne/Nndwa ya vhuhosi}

\subsection{History of the Vhavenda Kinship/Divha zwa kale ya vhuhosi ha Venda}

The Vhavenda people, just like many other South Africans, originate from the great lakes of central Africa. ${ }^{9}$ The Vhavenda people first settled at the Soutpansberg Mountains and built their first capital known as 'D'zata. ${ }^{10}$ The Venda culture has a remarkable combination of other cultures and is comprised of Nguni, Central African and Sotho characteristics. ${ }^{11}$ The Kingdom of Mapungubwe emerged in 800 AD and stretched from the Soutpansberg Mountains in the South and across the Limpopo River to the Matopos in the North. ${ }^{12}$ The Mapungubwe kingdom encountered a decline from 1240 AD which occasioned the movement of the epicenter of trade and power to the

3 J Modiri 'Conquest and constitutionalism: first thoughts on an alternative jurisprudence' (2018) 34 South African Journal on Human Rights 320.

4 DD Ndima 'The African law in the 21st century in South Africa' (2003) 36 Comparative and International Law Journal of Southern Africa 327.

5 Constitution of the Republic of South Africa, 1996 Preamble.

6 Bhe and Others $v$ Khayelitsha Magistrate and Others 20051 SA 580 (CC) (hereafter 'Bhe') para 87; Shilubana and Others v Nwamitwa 20089 BCLR 914 (CC) (hereafter 'Shilubana') para 31.

$7 \quad$ Ndima (n 3 above) 327.

8 As above.

9 Siyabona Africa http://www.krugerpark.co.za/Kruger_Park_Reference_Guidetravel/kruger-park-culture-guide.html (accessed 05 May 2020).

10 As above.

11 As above.

12 As above. 
north of the Kingdom of Great Zimbabwe. ${ }^{13}$ In the south of Limpopo, Shona-Venda and the Venda stoneware styles advanced during the 14 th and the 15 th centuries. ${ }^{14}$

Thoho-ya-ndou's home was known as D'zata and the remains of it have since been declared a national monument. ${ }^{15}$ D'zata was immensely significant for the Venda people and they buried their chiefs facing it. ${ }^{16}$ When Thoho-ya-ndou passed away, disputes were raised pertaining to succession and this led to separations which brought about the establishment of different houses. ${ }^{17}$ The Vhavenda people's culture concerning the succession of the throne is very compound, and their history has shown that it is usually accompanied by disputes with regards to who ought to succeed. ${ }^{18}$ The dispute which arises in the Mphephu case is thus not something new but rather presents a unique set of facts wherein a woman's position as a successor is being challenged. ${ }^{19}$ The complex nature surrounding the law of succession within the Vhavenda culture is the reason why this study calls for the transformation of customary law. ${ }^{20}$

When tracing the Vhavenda kinship, the lineage obtained from the first king to the current contested one is as follows: (1) Mambiri (2) Tshilume (Munzhedzi) (3) Tshikalanga (4) Hwami (5) Ntidime (6) Dimbanyika/Lunonye (7) Dyambeu/Vele la Mbeu (8) Thohoyandou (Phophi) (9) Mpofu (10) Ramabulana (Munzhedzi) (11) Makhado (Lion of North) (12) Mphephu/Tshilamulele (Bufallo) (13) Mbulaheni George (14) Ramaano Patrick (15) Phophi Mphephu (Acting) (16) Toni Peter Mphephu. ${ }^{21}$ When one looks at this lineage, certain observations are worth entertaining. For example, a woman has never led the Vhavenda kingship/queenship except for Phophi Mphemphu (Makhadzi) who was a leader in-acting. ${ }^{22}$ This exclusion of women is one of the reasons why the royal family rejects Masindi's claim to the throne. ${ }^{23}$ In an exclusive interview with 'Zwa maramani', Makhadzi submits that a woman cannot ascend to the throne and that if a woman could, she would have been queen herself. ${ }^{24}$ This is one of the arguments presented in this study, that rejecting Masindi's claim to the throne based on her gender is unconstitutional and subsequently promotes the principle of male primogeniture which was challenged

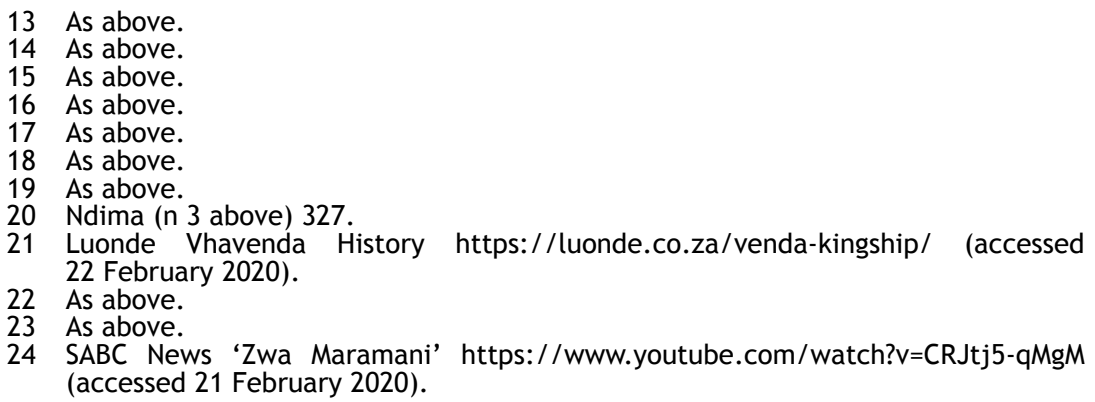

24 SABC News 'Zwa Maramani' https://www.youtube.com/watch?v=CRJtj5-qMgM (accessed 21 February 2020). 
in the Bhe and Shilubana judgment. ${ }^{25}$ These two cases are discussed in the latter paragraphs in great detail.

To enhance the argument that this study presents, focus will only be on how Toni emerged as the king of the Vhavenda tribe and why Masindi has a claim to the throne. Before Toni ascended to the throne, the Vhavenda kingship was contested by two other royal families, namely, the Ravhura family and the Mphaphuli family. ${ }^{26}$ In January 2010 the Commission on Traditional Leadership Disputes and Claims (the old Commission) decided that the Vhavenda kingship/queenship hould vest in the Mphephu family. ${ }^{27}$ As a result, the Vhavenda kingship/queenship now vests with the Mphephu family. The subsequent issue which arises questions who in the Mphephu family should be king/queen. This study responds in favour of Masindi throughout its discourse, and an argument that Masindi's pronouncement as queen will be a step towards the transformation of customary law is presented. ${ }^{28}$

Masindi is the only child of the late king Dimbanyika. ${ }^{29}$ When her father passed away in 1997 from a motor vehicle accident, Masindi was supposed to be nominated to be queen by the Makhadzi. Makhadzi is responsible for the nomination of the king/queen but was unable to nominate Masindi as she was only six years old at the time. ${ }^{30}$ It is however argued that despite this, Masindi should have been recognised as the rightful heir to the throne and a regent should have been appointed until Masindi became of age. ${ }^{31}$ Indeed a regent (which is the currently contested king Toni) was appointed but Masindi was overlooked entirely because she was a girl. ${ }^{32}$ That is why to date, the regency of the currently contested king Toni has been legitimised to kingship. There is indeed no argument concerning the question of whether Masindi is the rightful heir or not. The only point of contention is that she is a girl child. This argument does not hold because in the Bhe case, the Constitutional Court held that male primogeniture, which prefers male successors over female successors was unconstitutional as it violated section 9 of the Constitution. ${ }^{33}$ To give context to the matter pertaining to Masindi, the Bhe case will now be discussed.

25 Bhe (n 5 above) para 87.

Luonde Vhavenda History (n 20 above).

As above.

Ndima (n 3 above) 327.

Luonde Vhavenda History (n 20 above).

As above.

As above.

As above.

3 Bhe (n 5 above) para 87. 


\subsection{The court's approach in previous cases/Ndila ya khothe kha milandu yo fhiraho}

In the Bhe case, an application was brought on behalf of Ms Nontupheko's two minor daughters and her partner who is now deceased. ${ }^{34}$ Ms Nontupheko and her deceased partner were not married but they lived together during the course of their relationship until the deceased passed away. ${ }^{35}$ The deceased also took care of Ms Nontupheko and her two daughters. ${ }^{36}$ Upon the deceased's death, the relationship between Ms Nontupheko and the deceased's father broke down. ${ }^{37}$ Notwithstanding the breakdown of this relationship, the deceased's father was appointed as the representative and sole heir of the deceased's estate in terms of section 23 of the Black Administration Act. ${ }^{38}$

The question that the court was faced with in the Bhe case is the same question that this study is confronted with. ${ }^{39}$ The contention was that section 23 of the Black Administration Act and section 1(4) (b) of the Intestate succession Act amounted to unfair discrimination against Ms Nontupheko's two daughters and violated their right to human dignity. ${ }^{40}$ This was also the contention in the Shilubana case which is dissected in the latter paragraphs. Langa DCJ, who writes the majority judgment firstly notes that there is a place for customary law in our constitutional dispensation, and this does not presuppose that customary law should be tolerated, but rather accommodated. ${ }^{41}$ This statement made by the DCJ is susceptible to critique but that is discourse for another day. The most important thing that we ought to take away from this statement is that customary law applies in South Africa to the extent that it is not in conflict with the Constitution of the Republic of South Africa, $1996 .{ }^{42}$ Langa DCJ writes that section 39(2) of the Constitution imposes a duty on courts to interpret customary law in a way that promotes the spirit, purport and object of the Bill of Rights. ${ }^{43}$ Accordingly, although customary law rules apply in South Africa, they are not immune to constitutional scrutiny. ${ }^{44}$

Langa DCJ confirms the constitutional invalidity of section 23(10) (a), (c) and (e) of the Black Administration Act made by the Cape High 
Court. ${ }^{45}$ He writes that these sections unfairly discriminate against Ms Nontupheko's daughters on the ground of gender, and that this also amounts to the violation of their right to human dignity. ${ }^{46}$ He explains that courts should be careful not to blindly apply 'official' customary law at the expense of 'living' customary law, which is in harmony with transformation. ${ }^{47}$ In conclusion, Langa DCJ asserts that the notion of male primogeniture is unconstitutional as it unfairly discriminates against women and children born out of wedlock. ${ }^{48}$ This case is very significant in the argument that is presented throughout this study, which is seeks to invalidate the argument that denies Masindi her title as queen on the basis of her being a woman. ${ }^{49}$ Customary law is not immune to the constantly changing and moving society and the reason why Langa DCJ speaks of 'living' customary law is because society is constantly changing. Consequently, customary law should be in touch with society's ever-changing values, practices and needs. ${ }^{50}$

The minority judgment in this case also concurred with majority judgment in so far as to conclude that section 23 of the Black Administration Act and section 1(4) (b) of the Intestate succession Act were unconstitutional. ${ }^{51}$ The only dissenting part of the minority judgment held that, although the principle of male primogeniture unfairly discriminates against women, the principle does not unfairly discriminate against younger children because it aims to ensure that someone takes over the responsibility of taking care of the children. ${ }^{52}$ The dissenting remarks do not influence the argument that is presented throughout this study. However one could argue that the point raised by the minority judgment is ignorant of the fact that Ms Nontupheko was available to play that role. Replacing the deceased as a bearer of responsibilities is not inherently linked to gender and the argument would hold if there was no one else to take care of the children, where strict constitutional scrutiny and the best interests of the children would have to be taken into account.

In the Shilubane case, Ms Shilubane was the daughter of Hosi Fofoza Nwamitwa (hereafter 'Hosi Fofoza') and she is the one who brings an application to the court against Mr Nwamitwa, whose father is Hosi Malathini Richard Nwamitwa (hereafter 'Hosi Richard'). ${ }^{53}$ The dispute arises when Hosi Fofoza passed away without a male heir in 24 February $1968 .{ }^{54}$ The principle of male primogeniture came into

Bhe ( $\mathrm{n} 5$ above) para 93.

Ndima (n 3 above) 327.

Bhe (n 5 above) para 224.

As above.

Shilubana (n 5 above) para 3.

As above. 
play and even though Ms Shilubane was the oldest daughter of the deceased Hosi Fofoza and she was old enough to succeed him, she was overlooked. ${ }^{55}$ Consequently, Hosi Richard who was Hosi Fofoza's younger brother, was preferred over Ms Shilubana. ${ }^{56}$ The arguable point of law that arises, in this case, is similar to the one in the Bhe case, namely, that of the constitutional validity of the principle of male primogeniture. 57

The Constitutional Court had to determine whether the decisions of both the SCA and the High Court to declare the pronouncement of Ms Shilubane as Hosi as unlawful, were correct. ${ }^{58}$ Both these courts had held that the Royal Family had no authority to pronounce on Ms Shilubana as Hosi. ${ }^{59}$ The Constitutional Court however reasons in the same way as it did in the Bhe Case. In addition to this, the majority judgment held that section $211(2)$ of the Constitution allows traditional leaders of families to have their own systems and it is in line with constitutional values for royal families to develop their customary laws in accordance with the needs, values and circumstances of their communities. ${ }^{60}$ This is furthermore in line with 'living' customary law, which Ndima argues should be the system of customary law that the courts and the legislature adopt. ${ }^{61}$ The Court subsequently concluded its judgment by submitting that the principle of male primogeniture is unconstitutional and that the royal family was correct in pronouncing Ms Shilubana as Hosi. ${ }^{62}$

The court emphasises the fact that one cannot argue that someone cannot succeed merely because of their gender. ${ }^{63}$ This judgment promotes the argument presented throughout this study. When Masindi's father passed away, Masindi like Ms Shilubana, was supposed to succeed and the only difference in this scenario is that Masindi was still very young. ${ }^{64}$ Toni was instead appointed to be a regent until Masindi is of age but now Toni's regency has been legitimalised to kingship merely based on the argument that Masindi is a girl child. ${ }^{65}$ This decision is influenced by the principle of male primogeniture which has been shown, through the Bhe and Shilubane cases, as being unconstitutional and accordingly invalid. ${ }^{66}$

55 As above.

56 Shilubana (n 5 above) para 3.

57 Bhe (n 5 above) para 93.

58 Shilubana (n 5 above) para 1.

59 As above.

60 Shilubana (n 5 above) para 45.

61 Ndima (n 3 above) 327.

62 Shilubana (n 5 above) para 31.

63 As above.

64 Luonde Vhavenda History (n 20 above).

65 As above.

66 As above. 


\subsection{The Mphephu SCA decision/Khathulo ya khothe ya khathululo kha mulandu wa Mphephu}

The facts of the case are apparent in the above paragraphs, but to reiterate, Masindi is fighting for her rightful place as the queen of the Vhavenda kingdom. ${ }^{67}$ In this part of the study, focus is on how the court dealt with the merits of the case and whether the court reached the correct decision. The SCA in the Mphephu v Mphephu case had to determine whether the High Court was correct in dismissing Masindi's claim for the declaration of Toni's kingship of the Vhavenda people. ${ }^{68}$ The High Court held that it did not have jurisdiction over the dispute because the dispute had not been lodged first with the Commission in terms of section 21 of the Frameworks Act. ${ }^{69}$ This Act provides for lodging of claims, the declaration of disputes over traditional positions and the resolutions of these claims and disputes by the Commission. ${ }^{70}$ This resulted in the High Court not adjudicating on the issue of whether Toni is the rightful king or not. ${ }^{71}$

The SCA held that the High Court was mistaken in ruling that it didn't have jurisdiction and thus referred the matter back to the High Court for reconsideration. ${ }^{72}$ It held that the procedure given in sections 9(3) and 21 of the Frameworks Act were designed in such a way that by the time a dispute is raised in the courts, the customary institutions or structures: specialist entities on customary laws and custom, shall have had the chance as a matter of preference, to express their views on the customary laws and customs rules applicable. ${ }^{73}$ Moreover, the views of these institutions as overseers of customary law forms a part of the record of the decision. ${ }^{74}$

Furthermore, the SCA held that the Commission did not have the ecessary authority to identify a person for the recognition of a king or queen. ${ }^{75}$ It held that such authority or powers vested in the Royal Family, and in this instance, would vest with the Makhadzi (the sister of the incumbent ruler) of the Mphephu royal family. ${ }^{76}$ In essence, according to the Vhavenda customs, the king or queen is nominated by Makhadzi. ${ }^{77}$ Consequently, the SCA held that the decision by the eighth Respondent, who was the former president Jacob Zuma, to nominate Toni as king was unlawful. ${ }^{78}$ As a result and as things stand, 
Toni is, legally speaking, not the rightful heir and it can be said that the Vhavenda kingship/queenship is vacant unless if there is currently a regent appointed in the interim. The court further held that the argument that Masindi cannot be queen because she is a woman does not stand because it is established law that women can succeed as held in the Shilubana case. ${ }^{79}$

\section{Critical Analysis/Tsenguluso}

The first thing to note is that there is no dispute that Masindi is the rightful heir. The only dispute, as per the Makhadzi of the Mphephu royal family, is that Masindi is a woman and nowhere in the history of the Vhavenda kingship has a woman been a queen. ${ }^{80}$ Makhadzi argues that if this was the case then she would have been the queen herself. ${ }^{81}$ The only difference between Makhadzi and Masindi is that Masindi wants to be queen at a time when there is a constitution, which is the supreme law and all laws, including customary law being subject to it. ${ }^{82}$ Section 9 of the Constitution states that no one may be discriminated against on the basis of sex, gender, race and so forth. ${ }^{83}$ This means that any custom, including the Vhavenda custom, which discriminates against any person based on any ground listed in section 9 of the Constitution will be declared unconstitutional. ${ }^{84}$ Therefore, the argument made that Masindi cannot be queen because it is against the Vhavenda custom, is unconstitutional. This is an established principle which was adopted in the Shilubana case where it was clearly stated that women can succeed. ${ }^{85}$

This study expands and explores upon Ndima's text where he writes about the dichotomy between 'official' customary law and 'living' customary law. ${ }^{86}$ Ndima writes that the old 'official' customary law encompasses old customary law rules which were infiltrated and to a lesser or greater extent fabricated by Western civilisation. 87 Consequently, 'official' customary law has been stripped of the moral values of Africans due to the application of repugnancy clauses which have left African law distorted beyond recognition. ${ }^{88}$ 
In contrast, 'living' customary is in touch with society's values, needs and circumstances. ${ }^{89}$ It moves with time and it is the one that African communities continue to adhere to. ${ }^{90}$ Ndima contends that 'living' customary law is the one that should be affirmed by the courts and the legislature. ${ }^{91}$ The reason why the Bhe and Shilubana judgments are adopted in the argument presented throughout this study is that both these judgments speak of the need for courts to follow 'living' customary law. 92 'Living' customary law would dictate that the African values of Ubuntu, as dissected above, be followed and that would result in Masindi being allowed to be queen. ${ }^{93}$ Moreover, 'living' customary law, which is transformative, would acknowledge that the principle of male primogeniture should no longer apply since society is constantly moving and changing. ${ }^{94}$ Accordingly, the adoption of 'living' customary law by courts is a step towards the transformation of customary law.

Toni's legitimacy as king was declared by former president Jacob Zuma in 2012. ${ }^{95}$ The SCA held that this declaration by the president was unlawful as he acted out of jurisdiction. ${ }^{96}$ This means that as things stand, the Vhavenda kingship is vacant. Toni is not legally permitted to call himself the king of the Vhavenda kingship/ queenship. The High Court will then decide on the issue of who the rightful heir is provided that the Mphephu Ramabulana family fails to resolve the matter within the family. However, the High Court is likely to reach the same conclusion that this study reaches as it is bound to the decisions of the Constitutional Court as well as the Constitution itself, which inspires to be transformative adjudication. ${ }^{97}$

The SCA makes a very progressive remark in its judgment. It reveals that it would be in the parties' best interest to sit as a family and try to resolve the matter before the matter is heard by the High Court again. ${ }^{98}$ This remark indicates that the SCA acknowledges the superiority of the Constitution but also tries to respect customary law by showing reluctance in dictating or commanding the Royal Family on what it ought to do. In this regard, the SCA's decision is commendable. The remarks by the SCA means that the Royal Family should negotiate amongst each other or in the presence of the

89 As above.

90 As above.

91 As above.

92 Bhe (n 5 above) para 239; Shilubana (n 5 above) para 76.

93 Ndima (n 3 above) 327.

94 As above.

95 E Mushiana 'We have accepted the decision of the court, says Mphephu royal family' 15 May 2019 https://citizen.co.za/news/south-africa/courts/2116761/ appeal-court-sets-asidezumas-decision-that-made-vbs-linked-man-venda-king/ (accessed 22 March 2020).

96 Mphephu (n 66 above) para 43.

97 PN Langa 'Transformative constitutionalism' (2006) 17 Stellenbosch Law Review 353.

98 Mphephu (n 66 above) para 43. 
necessary stakeholders if needs be. The negotiations would mean that there must be a compromise. In the succeeding paragraphs, potential solutions that entail potential compromises are provided.

The Mphephu Ramabulana family can also employ the transformative stance taken by the Valoyi family in the Shilubana case if it believes that it is against their customary law rules for a woman to be a queen. ${ }^{99}$ The court in Shilubana says that the Royal Family can develop its rules to be in line with the ever-changing society. ${ }^{100}$ Nothing is standing between Masindi and the throne except the conflict in the family. The family may also employ the spirit of Africanness 'Ubuntu' or 'vhuthu' in Tshivenda. The court in $S v$ Makwanyane (hereafter 'the Makwanyane case') introduces us to the principle of Ubuntu in judicial review. The Constitutional Court held that Ubuntu has become a very important part of our constitutional values and is one of the values that ought to be considered when interpreting the Bill of Rights as well as other areas of law. ${ }^{101}$

This study also expands and explores upon Ntlama who writes about the need for traditional leadership to be transformed. ${ }^{102}$ This has been the call that this study has been making throughout its discourse. Ntlama reveals how difficult it has been in customary law for women to be treated as equals. ${ }^{103}$ Many traditional leadership institutions are presided over by men who disregard women. ${ }^{104}$ The argument concerning the existence of traditional leadership in 'post'apartheid South Africa is discourse for another day. While in existence, traditional leadership like most institutions in South Africa and probably all over the world, needs to be stripped of its patriarchy. ${ }^{105}$ The continual domination and subjugation of women by traditional leadership institutions should be dismantled. ${ }^{106}$

The pronouncement of Masindi as queen of the biggest house of the Vhavenda people can help in dismantling the idea of male domination in traditional leadership institutions. ${ }^{107}$ It would be unjust for us to call for the transformation of South Africa in unanimity but begin to scatter when we call for the transformation of traditional leadership within South Africa. A transformed traditional leadership institution would have different attributes depending on the traditional practices of each community. However, what should be

99 Shilubana (n 5 above) para 31.

100 As above.

101 S v Makwanyane and Another 19953 SA 391 (CC) (hereafter 'Makwanyane') para 225.

$102 \mathrm{~N}$ Ntlama 'The Changing Identity on Succession to Chieftaincy in the Institution of Traditional Leadership: Mphephu v Mphephu-Ramabulana (948/17) [2019] ZASCA 58' (2020) 23 Pioneer in Peer Review 3.

103 Ntlama (n 101 above) 3.

104 As above.

105 As above.

106 As above.

107 Ndima (n 3 above) 327. 
common in all traditions is that the domination and subjugation of women must be done away with. Women must be seen as equals to their male counterparts and they should have equal access to opportunities. The cases that this study explores have shown that the application of 'living' customary law by courts is significant in the call for the transformation of customary law.

The Makwanyane case is important because it introduces Ubuntu in judicial review and emphasises the value that Ubuntu puts on life and human dignity. ${ }^{108}$ This means that courts can use Ubuntu to justify their reasoning in judgments. ${ }^{109}$ The consequence of this also means that the High Court can adopt Ubuntu if it hears the Mphephu case again in the event where the family is unable to resolve the dispute on its own. However, for an illustration of Ubuntu as a concept, the discussion laid out in the Makwanyane case will not be followed. ${ }^{110}$ This study expands and explores upon an article titled 'Reflections on judicial views of Ubuntu' by Himonga, Taylor and Pope, who contend that the discussion on the concept itself and its origin in the Makwanyane case is prone to redundancy, ambiguity, issues of exclusions and perceptions of dichotomies. ${ }^{111}$

The challenge with the concept of Ubuntu as laid down in the Makwanyane case lies in the interpretation of what this concept means or denotes. ${ }^{112}$ These authors note that the court in Makwanyane does not give us the direction on which mutually exclusive interpretation is to be followed. ${ }^{113}$ The authors however submit that a jurisprudentially inspired concept of Ubuntu would be one that leads to the realisation of a democratic society based on human dignity, equality and freedom. ${ }^{114}$ It must, however, be noted that the authors do not oppose the idea of Ubuntu as humanness, compassion, and so forth but merely argue for legal certainty in judicial review. ${ }^{115}$

When one looks at the Mphephu case, it is advised that Ubuntu be employed by the family in their discussions to find a solution. If the family can only show compassion, love and humanness then it is possible that they can come to a compromise that would allow Masindi as the rightful heir to lead. Ubuntu would also presuppose the notion that society is constantly changing, and transformation is for that reason essential. If the family does not reach such a compromise then the High Court must use Ubuntu to realise the democratic values of

108 Makwanyane (n 100 above) para 225.

109 As above.

110 As above.

111 C Himonga et al 'Reflections on judicial views of Ubuntu' (2013) 16 Potchefstroom Electronic Law Journal 50.

112 Himonga (n 110 above) 50.

113 As above.

114 As above.

115 Himonga (n 110 above) 50. 
equality, human dignity and freedom, and this can only be achieved through allowing Masindi, as the rightful heir, to lead. Masindi's taking over as the rightful heir of the biggest royal family in the Vhavenda culture is also a step towards the transformation of traditional leadership in South Africa. This will show that the rigid rules and beliefs of subjugation and dominion over women are cast away.

It is not an issue of contestation that Masindi is the rightful heir. The only challenge was that she was overlooked because of her gender and this is an issue this study has already laid to rest in the preceding paragraphs. Now the issue that is ought to be determined is whether Masindi can be queen. One of the issues raised each time we speak about queenship is that of 'continuation'. This is also argued in the battle of the Mphephus. The argument is, if Masindi is to be the queen then the chieftaincy will move to another bloodline or family. ${ }^{116}$ But a good question which then arises is, what if Masindi has no intention of getting married? Transformation also entails the notion that women should be free to decide what they want to do and what they don't. If Masindi decides that she does not want to get married, then she should still be able to become queen and thereafter, any person in line can lead. She cannot just be overlooked merely on the grounds that she is a woman or because it is supposedly every woman's desire to get married.

Furthermore, this study dismisses the argument of 'continuation' as a basis for rejecting Masindi's claim to her throne by expanding and exploring upon the Modjadji royal family. The Rain Queen was married to a woman and her brothers were responsible for procreation to ensure that the bloodline remains in one family. ${ }^{117}$ The children born from that procreation are the children of the Rain Queen. ${ }^{118}$ This is also one thing that the Mphephu family may look into. ${ }^{119}$ Masindi be can Queen given that she complies with the conditions set by the Royal Council. These conditions may include but are not limited to the following; Masindi may not have children unless it is through the route followed by the Modjadji family, Masindi may relinquish any desire to get married to a man unless she does not plan on having children with that spouse and she may accept her uncle Toni as a Ndumi (close advisor) in exchange for Toni stepping down from the kingship to maintain peace in the family. This is essentially what transformation entails, an understanding that the society is not stagnant, society is constantly changing, and laws, customary law included, should avoid being out of touch with the society.

116 SABC News 'Zwa Maramani' (n 23 above).

117 National Museum Publications https://nationalmuseumpublications.co.za/modja dji-the-rainqueen/ (accessed 22 February 2020).

118 National Museum Publications (n 116 above).

119 As above. 


\section{Conclusion/Magumo}

The battle of the Mphephus is characterised by one thing and one thing only, that is, the principle of male primogeniture and how it disallows or sees women as incapable of leading. This principle was declared unconstitutional in the Bhe case, and the Shilubana case also made it clear that a woman can succeed. The argument with regards to the issue of continuation also does not provide an uncontested logic because Masindi may choose not to get married or she may choose to get married to a woman, following the example of the Rain Queen, and not have children. The family during their negotiations can adopt Ubuntu to reach a compromise or if no such compromise is reached then the High Court can also adopt Ubuntu in deciding the matter. Central to this case is the transformation of traditional leadership institutions. Masindi as the rightful heir must be allowed to be queen and the Royal Family, for the sake of peace and Ubuntu must make his uncle, Toni a Ndumi (close advisor).

Nndaa!! 